\title{
Bio-efficacy of potassium phosphonate against nut rot disease of areca nut (Areca catechu L.) in the northern Karnataka of India
}

\author{
G.M. Hegde
}

\begin{abstract}
Phytophthora arecaea, a causal agent of nut rot disease (koleroga) of areca nut (Areca catechu L.) is one of the major fungal pathogens affecting the crop in the northern Karnataka of India. The estimated loss associated with this disease extends up to $60 \%$. In the endemic regions of India, the disease occurs immediately after the onset of the monsoon rains (June) and prevails till mid-August due to congenial weather conditions. For the effective management of this devastating disease, potassium phosphonate was tried during June and July 2013-2014 at the farmer's fields. The results revealed that potassium phosphonate applied at the rate of $6.0 \mathrm{ml} / \mathrm{L}$ has reduced the per cent disease incidence (PDI) in areca nut (PDI=19.5\%), where the results were on par ( $\mathrm{p}>0.05)$ with metalaxy $\mathrm{MZ}$ applied at $2.0 \mathrm{~g} / \mathrm{L}(\mathrm{PDI}=16.81 \%)$ and Bordeaux mixture applied at $1 \%(\mathrm{w} / \mathrm{v} ; \mathrm{PDI}=18.84 \%)$. However, potassium phosphonate at $3.0 \mathrm{ml} / \mathrm{L}(\mathrm{PDI}=43.10 \%)$ and $4.5 \mathrm{ml} / \mathrm{L}(\mathrm{PDI}=39.45 \%)$ was not effective in reducing the PDI. The maximum PDI of $52.87 \%$ was recorded in unsprayed control plots. The highest yields of $26.42 \mathrm{q} / \mathrm{h}$ was recorded from the plots sprayed with metalaxy $M Z$ at $2.0 \mathrm{~g} / \mathrm{L}$, which is in par ( $p>0.05$ ) with potassium phosphonate applied at $6.0 \mathrm{ml} / \mathrm{L}(24.76 \mathrm{q} / \mathrm{ha}$ ) and Bordeaux mixture at $1 \%$ (25.12q/ha). The lowest yield (12.48 $\mathrm{q} / \mathrm{ha}$ ) was recorded from the control (unsprayed) plots.
\end{abstract}

Keywords: Areca nut, Phytophthora arecaea, nut rot disease (koleroga), potassium phosphonate

\section{Introduction}

Areca nut (Areca catechu L.), popularly known as betel nut, is an important plantation crops in India. This crop is being grown in an area of $0.38 \mathrm{~m}$ ha with an annual production of $0.48 \mathrm{mt}$ in major cities such as Karnataka, Kerala, Assam, Maharashtra, West Bengal and Tamilnadu of India (Jose et al., 2008). India leads in the cultivated extent and production of areca nut and also in average yields of the crop. Other main countries growing areca nut are Bangladesh, Sri Lanka and Malaysia. In Karnataka of India, Uttara Kannada is one of the major areca nut growing districts and the estimated production is $16,700 \mathrm{mt}$ from an area of 12,290 ha. Although India has attained self-sufficiency in this crop, koleroga (nut rot) caused by Phytophthora arecae is the major production constraint in areca nut (Rather et al., 1982).

This disease occurs during the south west monsoon season and results in heavy dropping of nuts from bunches and the death of the palms at advanced

College of Forestry, University of Agricultural Sciences, Dharwad, Karnataka, India.

gurudatthegde@gmail.com 
stages (Kamath, 1953; Sastry, 1982). The previous records on crop losses due to nut rot varied from 10-90\%, and due to bud rot the crop losses is about $15 \%$ (Coleman and Rao, 1918).

The disease is characterized by sudden heavy shredding of immature nuts, which lies scattered near the base of the palms. On closer observations of the nuts, dark coloured white lesions are seen near the perianth. The control measures suggested by the previous workers to control the disease comprised of either providing covers made out of areca nut leaf sheaths (kotte) or dried grass (karada) to areca nut bunches or spraying Bordeaux mixture $(1 \% \mathrm{w} / \mathrm{v})$ to the bunches 2-3 times (Narasimhan, 1922). However, the covers could either dislodged or be damaged by heavy winds or deteriorate during the rains in the monsoon resulting rainwater percolation into bunches providing favorable condition for Phytophthora infection. In case of Bordeaux mixture sprays, the difficulty lies with use of calcium carbonate and copper sulphate of various qualities and difficulties in application during the rains. Spraying with Bordeaux mixture followed by covering bunches with polythene has also been suggested in the recent past as a better technique to manage the disease however, being time-consuming and laborious nature of the activity has failed in acceptance by farming communities. Hence, identification of chemicals that has both fungicidal properties and providing nutrition to be used immediately after the occurrence of the disease to minimize the yield losses was considered important to control the disease as well as to promote crop growth. The present study was undertaken to evaluate the bio-efficacy of a new molecule potassium phosphonate (Phosfik $8^{\circledR}$ ) in managing koleroga of areca nut in the endemic region of Uttara Kannada district in India.

\section{Materials and Methods}

Farmers plot at Bilaghi village of Siddapur Taluk of Uttara Kannada district in India was selected for the experiment during kharif 2013-2014, which was situated in valleys with thick perennial trees on both sides. The humidity during the rainy season was almost $100 \%$ and the gardens were prone to koleroga infestation during the previous years. The experiment was conducted in a randomized complete block design (RCBD) with seven treatments and three replicates. The plot size was $13 \mathrm{~m} \mathrm{X} 8 \mathrm{~m}$ with spacing of $1.2 \mathrm{mX} 1.2 \mathrm{~m}$. In each treatment 20 palms were considered for observations. During the south west monsoon (kharif) of 2013-2014, the field experiment was laid out to investigate the efficacy of various concentrations of potassium phosphonate (Phosfik $8^{\circledR}$ ). Prophylactic spray with Bordeaux mixture ( $1 \%$ ) and market sample of potassium phosphonate applied at 3\%, metalaxyl MZ at $0.2 \%$ was also used (Table 1 ). 
Table 1. Treatment structure

\begin{tabular}{|c|c|c|c|}
\hline $\begin{array}{l}\text { Serial } \\
\text { No. }\end{array}$ & Treatments & Dosage $(\mathrm{ml} / \mathrm{L})$ & $\begin{array}{c}\text { Application Time \& } \\
\text { Method }\end{array}$ \\
\hline 1 & Potassium phosphonate- 8 & 3.0 & \multirow{5}{*}{$\begin{array}{l}\text { The first spray was given } \\
\text { immediately after the } \\
\text { onset of the disease anc } \\
\text { subsequent spray at } 30 \\
\text { days interval using gutter } \\
\text { sprayer. }\end{array}$} \\
\hline 2 & Potassium phosphonate- 8 & 4.5 & \\
\hline 3 & Potassium phosphonate- 8 & 6.0 & \\
\hline 4 & $\begin{array}{l}\text { Potassium phosphonate- } 8 \\
\text { (market sample) }\end{array}$ & 3.0 & \\
\hline 5 & Metalaxyl MZ 68WP & 2.0 & \\
\hline 6 & Bordeaux mixture & $1 \%$ & Used at 45 days interval. \\
\hline 7 & Control & --- & \\
\hline
\end{tabular}

\section{Per cent Disease Index (PDI) for Koleroga of Areca nut}

In each micro plot, five palms were randomly selected and graded for koleroga using 1-6 scale as given by Sastry and Hegde (1987; Table 2).

Table 2. Grading scale of koleroga (nut rot disease)

\begin{tabular}{cl}
\hline Grades & Description \\
\hline 1 & $1-10 \%$ nut fall from bunches \\
2 & $11-25 \%$ nut drop \\
3 & $26-50 \%$ nut drop \\
4 & $51-75 \%$ nut drop + spread of the disease to bunch stalk \\
5 & $76-100 \%$ nut drop + spread of the disease to the main stalk of the bunch \\
6 & Crown death \\
\hline
\end{tabular}

The PDI was calculated using Equation 1

Sum of Numerical ratings
Per cent Disease Index =
Total No. of plants x Maximum grade

The PDI and yields per palm were recorded and later analyzed by using standard statistical methods. The yields were converted in to $\mathrm{q} / \mathrm{ha}$.

\section{Results and Discussion}

The results revealed that potassium phosphonate applied at the rate of $6.0 \mathrm{ml} / \mathrm{L}$ (T3) significantly reduced the koleroga incidence in areca nut (19.48\% $\mathrm{p}<0.05$; Table 2) and has found on par with metalaxy $M Z$ at $2 \mathrm{~g} / \mathrm{L}(\mathrm{T} 5 ; 16.81 \%)$ and Bordeaux mixture at $1 \%(\mathrm{~T} 6 ; 18.84 \%)$. The market sample of potassium phosphonate (Akomine ${ }^{\circledR}$ ) applied at $3.0 \mathrm{ml} / \mathrm{L}$ showed a PDI of $36.18 \%$. However, potassium phosphonate applied at $3.0 \mathrm{ml} / \mathrm{L}(43.4 \%)$ and $4.5 \mathrm{ml} / \mathrm{L}$ (39.45\%) was 
inferior in reducing the PDI. The maximum PDI of $52.87 \%$ was recorded in the control (T7).

Table 2. Evaluation of Potassium phosphonate against koleroga in areca nut

\begin{tabular}{llcccc}
\hline \multirow{2}{*}{ No. } & Treatments & \multicolumn{3}{c}{ Per cent disease incidence (PDI) } & Yield \\
\cline { 3 - 5 } & & $\begin{array}{c}\text { Before } \\
\text { spray }\end{array}$ & After I spray & After II spray & q/ha \\
\hline 1 & Potassium phosphonate-8 at & 13.0 & 25.21 & 43.40 & 15.88 \\
& $3.0 \mathrm{ml} / \mathrm{L}$ & $(21.13)^{*}$ & $(30.13)$ & $(41.21)$ & \\
2 & Potassium phosphonate-8 at & 12.58 & 26.96 & 39.45 & 17.76 \\
& $4.5 \mathrm{ml} / \mathrm{L}$ & $(20.79)$ & $(31.24)$ & $(38.94)$ & \\
3 & Potassium phosphonate-8 at & 12.18 & 15.60 & 19.48 & 24.76 \\
& 6.0 ml/L & $(20.44)$ & $(23.26)$ & $(26.21)$ & \\
4 & Potassium phosphonate-8 at & 15.50 & 27.48 & 36.18 & 18.59 \\
& $3.0 \mathrm{ml} / \mathrm{L}$ (market sample) & $(23.19)$ & $(31.63)$ & $(36.99)$ & \\
5 & Metalaxyl MZ at 2.0 g/L & 13.14 & 13.28 & 16.81 & 26.42 \\
& & $(21.30)$ & $(21.39)$ & $(24.20)$ & \\
6 & Bordeaux mixture at $1 \%$ & 12.48 & 16.21 & 18.84 & 25.12 \\
& & $(20.70)$ & $(23.73)$ & $(25.70)$ & \\
7 & Control & 13.16 & 28.19 & 52.87 & 12.48 \\
& & $(21.30)$ & $(32.08)$ & $(46.66)$ & \\
& SEm+** & 1.01 & 1.07 & 1.11 & 1.12 \\
& CD $(\mathrm{p}=0.05) * * *$ & $\mathrm{NS}$ & 3.19 & 3.31 & 3.28 \\
\hline
\end{tabular}

*Values in parenthesis are angular transformed values; ** standard error of the means;

$* * *$ Critical difference

The highest yield of $(24.76 \mathrm{q} / \mathrm{ha})$ was recorded in the plots sprayed with potassium phosphonate at $6.0 \mathrm{ml} / \mathrm{L}(\mathrm{T} 3)$, which is in $\operatorname{par}(\mathrm{p}>0.05)$ with $26.42 \mathrm{q} / \mathrm{ha}$ in the plots sprayed with metalaxy MZ at $2.0 \mathrm{~g} / \mathrm{L}(\mathrm{T} 5)$ and Bordeaux mixture at $1 \%$ (T6; $25.12 \mathrm{q} / \mathrm{ha}$ ). The lowest yields of $12.48 \mathrm{q} / \mathrm{ha}$ was recorded in the untreated plots (T7) plots.

Among the various concentrations of potassium phosphonate evaluated, application of the chemical at the rate of $6.0 \mathrm{ml} / \mathrm{L}$ has significantly reduced the PDI and increased the yields. This is an agreement with Hegde and Mesta (2014) who reported that in cocoa, spraying with potassium phosphonate at $6.0 \mathrm{ml} / \mathrm{L}$ and drench at $4.0 \mathrm{ml} / \mathrm{L}$ has reduced the incidence of pod rot caused by $P$. theobromae. Phosphonate fungicides have been found to inhibit several key enzymes needed for growth and development of $P$. palmivora. It is also opined that the combined application of Trichoderma harzianum + potassium phosphonate significantly reduces the populations of Phytophthora causing foot rot of black pepper (Anon, 1997). It is assumed that the mode of action of potassium phosphonate did not involve killing the fungus directly rather it involved in a stimulation of the plants natural chemical and physical defenses against disease (Jahagirdar et al. 2000). However, spraying with metalaxyl MZ at 
$2.0 \mathrm{~g} / \mathrm{L}$ and Bordeaux mixture at $1 \%$ was in par with the potassium phosphonate. Ramachandran and Sarma (1985) reported that the systemic fungicide metalaxyl (Ridomil ${ }^{\circledR}$, Matco 8-64 ${ }^{\circledR}$ ) and Fosetyl Al (Aliette ${ }^{\circledR}$ ) both as foliar spray and soil drenching were effective against $P$. capsici in the field conditions. Similar results have been reported on the efficacy of metalaxyl against Phytophthora infections in black pepper (Sastry 1982; Anon 1986). This may be due to the reduced number of secondary inoculum due to the antisporulant activity of this fungicide there by restricting the rapid secondary spread of the disease.

The results conclude that two sprays at monthly intervals with potassium phosphonate (Phosfik 8 ) at the rate of $6.0 \mathrm{ml} / \mathrm{L}$ was effective in managing koleroga (nut rot disease) of areca nut.

\section{Acknowledgement}

Author is grateful to Shri Durga Biotech, Bangalore, India for the financial assistance on chemical analysis of the project conducted at the University of Agricultural Sciences, Dharwad, Karnataka, India.

\section{References}

Anonymous (1986): Annual Report, Central Plantation Crops Research Institute, Kasargod, Kerala.

Anonymous (1997): Annual Progress Report, Indian Institute of Spice Research, Calicut, Kerala, p. 101.

Coleman, L.C. and Venkatarao, M.K. (1918): The cultivation of areca palm in Mysore. General Ser. Bull. Dept. Agric. Mysore, pp 10-32.

Hegde, G.M. and Mesta, R.K. (2014): Cocophos (Potassium phosphonate) a new molecule to Manage pod rot disease in cocoa. In: $35^{\text {th }}$ Annual Conference and National Symposium on "Innovative and ecofriendly research Approach for Plant Disease Management". 9-10 January 2014. PDKV, Akola, India,

Jahagirdar, S., Siddaramaiah, A.L. and Chandrappa, H.M. (2000): Ecofriendly integrated management of foot rot of black pepper (Piper nigrum). Mysore J. Agric. Sci. 34(1): 47-54.

Jose, C.T., Balasimha, D., and Kannan, C. (2008): Yield loss due to Fruit rot disease and pests in Karnataka. Indian J. Arecanut Spices and Medicinal Plants 10(2): 1-5.

Kamath, M.N. (1953): Practical Plant Pathology. Prakash Publishing House, Pune. pp 200.

Narasimhan, M.J. (1922): The areca koleroga work during 1921. Mysore Agric. Calendar pp. 4-8.

Ramachandran, N. and Sarma, Y.R. (1985): Efficacy of three systemic fungicides in controlling Phytophthora infection of black pepper. Indian Phytopath., 38: 160162.

Rather, T.S.S., Nair, R.R. and Saraswathy, N. (1982): Diseases of Arecanut. Central Plantation Crops Research Institute, pp 185-218, Kerala, India,. 
Hegde

Sastry, M.N.L. (1982): Studies on species of Phytophthora affecting plantation crops in Karnataka with special reference to koleroga of arecanut and wilt of black pepper, Ph.D thesis, University of Agricultural Sciences, Bangalore. pp 188.

Sastry, M.N.L. and Hegde, R.K. (1987): Phytophthora associated with arecanut in Uttara Kannada, Karnataka. Current Science 56: 367-368. 